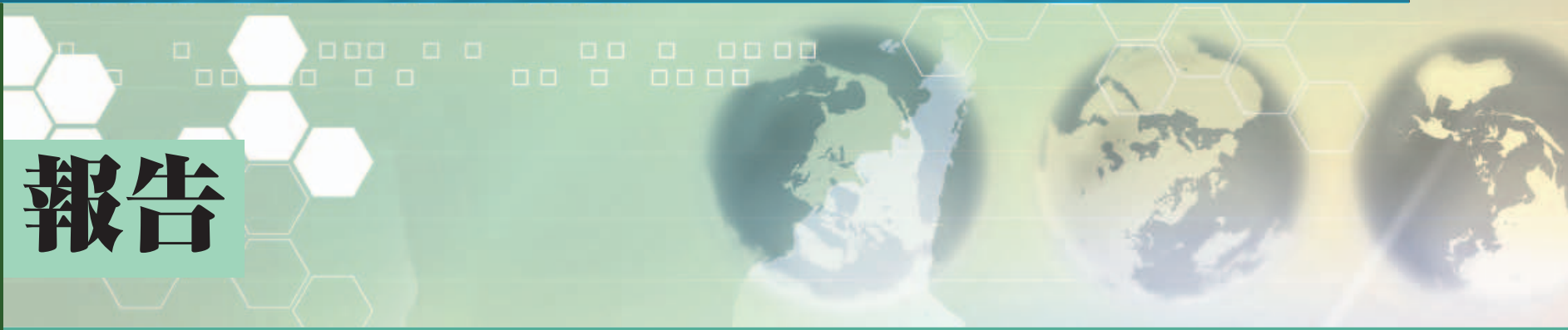

\title{
コグニティブ無線の標準化動向
}

\section{原田博司 独立行政法人情報通信研究機棈}

\section{1. まえがき}

現在, 光, モバイル, 情報家電の強みを生かしたワイヤレ スブロードバンドネットワークを駆使したユビキタスネット 社会の実現のために様々な研究開発が行われている.しかし, このようなワイヤレスネットワークを今後検討していく上に おいては様々な問題点がある.

一つ目は移動通信に適した周波数帯において深刻な周波数 不足の問題である [1]. 通信のブロードバンド化に伴い，今 後は数十 $\mathrm{MHz}$ から数百 $\mathrm{MHz}$ のまとまった帯域が必要にな る。しかし, 現状移動通信に適した VHF/UHF 帯から 6 $\mathrm{GHz}$ 以下の周波数帯に拈いてこのような帯域を確保するこ とは非常に難しい。 また, 世界無線通信会議 (WRC-07) にお いても第 3 世代及び第 4 世代移動通信システムで使用する周 波数帯域として新たに $3.4 〜 3.6 \mathrm{GHz}$ (200 MHz 幅), 2.3 〜 $2.4 \mathrm{GHz}$ (100 MHz 幅), $698 \sim 806 \mathrm{MHz}(108 \mathrm{MHz}$ 幅)，450 〜 $470 \mathrm{MHz}$ (20 MHz 幅) が割り当てられ，また，2011 年 7 月アナログテレビからディジタルテレビへ完全移行すること に伴う，(a） $90 \sim 108 \mathrm{MHz}$ (18 MHz 幅)，（b） $170 \sim 222$ $\mathrm{MHz}$ (52 MHz 幅)，(c) $710 \sim 770 \mathrm{MHz}$ (60 MHz 幅) の空 きチャネルに対しても，それぞれ，(a)放送系システム, (b) 公 共ブロードバンドシステム $(170 \sim 205 \mathrm{MHz})$, 放送系システ ム (205〜 $222 \mathrm{MHz})$, (c) ITS (715 725 MHz), 移動通信 システム $(730 \sim 770 \mathrm{MHz})$ に使用する方針が決定され，更に 2010 ～ 2015 年以降出てくる新しいワイヤレス通信システム に対応できるだけの十分な周波数帯域を確保することは難し くなる.

二つ目はユビキタスネット社会が進展するにつれ，無線機 が運用者の相互協力のないまま遍在し, 相互干涉のため所望 の伝送品質が得られない状況が多く見られているという問題 である．例えば, 無線 LAN, RFID タグはその代表例である.

このような干渉が顕著な環境においても必要な通信容量を できるだけ多く確保するためには今後電波利用環境を認知,
認識 (cognition) し，結果を理解 (comprehension) し，環境内 に存在する無線機が共存 (co-existence) できるワイヤレス利 用環境の実現が必要になる。このようなワイヤレス利用環境 を実現する一つの技術がコグニティブ無線技術であり，現在 内外で検討が行われている。本稿ではこのコグニティブ無線 技術の標準化動向についてまとめている.

\section{2. 本稿におけるコグニティブ無線技術の定義 とその導入シナリオ}

本稿におけるコグニティブ無線技術とは,「無線機が周囲の 電波利用環境を認識し，その状況に応じて無線機が適宜学習 等を取り入れつつ，ネットワーク側の協力を得ながらシステ ム内，システム間問わず複数の周波数帯域，タイムスロット， 等の無線リソース並びに通信方式を適宜使い分け，ユーザが 所望の通信容量を所望の通信品質で周波数の有効利用を図り つつ伝送を行う無線通信技術」と定義する [1]，そして，認識 結果，他に利用できる電波環境が存在する場合は，単一シス テム内であれば，システムに割り当てられた周波数帯のうち 場所や時間帯により現在使用されていない帯域，時間スロッ 卜を一時的に占有利用する。 また，異システム内であれば各 システム間に割り当てられた周波数帯のうち現在使用されて いない帯域, 時間スロットを一時的に占有利用する。そして, 所望の通信容量を所望の通信品質で周波数の有効利用を図り つつ伝送を行う.

そしてその導入のためのシナリオは図 1 に示す三つのもの が考えられる[2]。

（1）1番目は周波数の一次利用者（primary operator）が 行うコグニティブ無線技術である。ここでいう周波数の一次 利用者とは例えば携帯電話会社に代表される周波数使用のラ イセンスを受けた事業者(オペレータ)である。その利用者が 有する周波数帯域をユーザの希望に合わせて適宜割り当てて いくというものである.

（2）複数の (multiple) 周波数の一次利用者が行うコグニ 


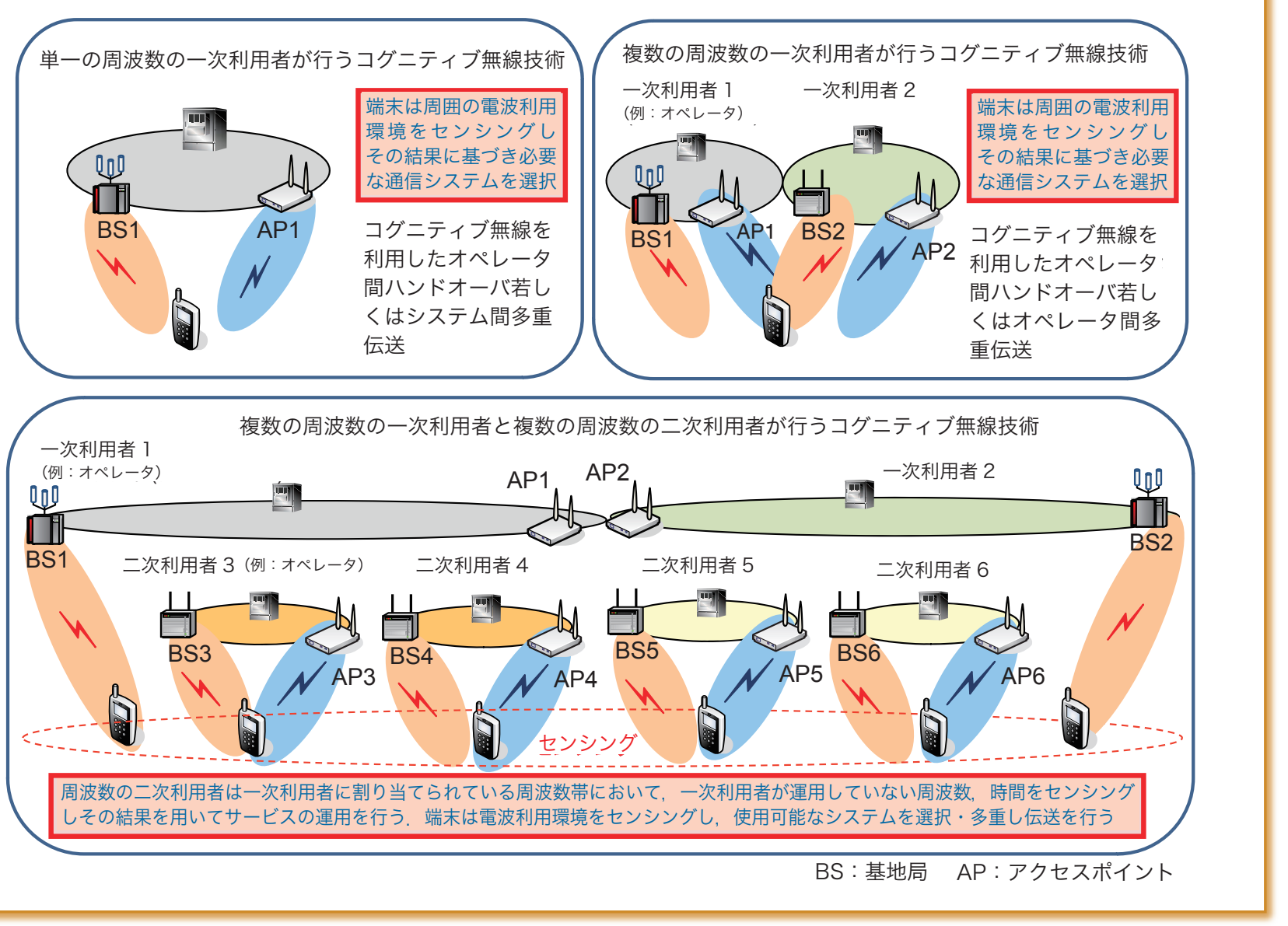

図 1 コグニティブ無線技術導入のためのシナリオ

ティブ無線技術である。これは複数の一次利用者に対して割 り当てられている周波数を利活用し, ユーザの希望に合わせ て必要となる周波数帯域を柔軟に適宜割り当てていくという ものである。この例としては, 例えば災害等で一つの携帯電 話会社のネットワークがつぶれた場合, 他の携帯電話会社が 有する周波数を自動的に利用して通信を行うことができるよ うにするという例と, 一つの携帯電話会社が有する回線と, 別の携帯電話会社が有する回線とを複数用い，ユーザに対し てよりブロードバンドな伝送を行うという例が考えられる.

（3）最終の展開は, 複数の周波数の一次利用者とその一 次利用者と同一の周波数を利用する二次利用者 (secondary operator）を認め, この一次と二次利用者が電波の利用環境 のセンシングを通じ周波数の有効利用を図りつつ共存するコ グニティブ無線技術である。一次利用者の周波数がすべての 場所で常に $100 \%$ 使用されているということはないので, 使 用されていない場合は二次利用者に利用させ, 総合的に周波 数の利用効率を上げるというものである.

このコグニティブ無線技術に関しては次の三つの観点から 標準化を行う必要性がある。

（1）コグニティブ無線技術という非常に広い意味をもつ 技術に対して, 共通認識をもたせるための, 言葉の定義, 基 本的な考え方についての標準化
（2）要素技術の標準化. 例えば，コグニティブ無線によ り周囲の電波利用環境の認識をし, その結果として異システ ム間でハンドオーバするための端末側とネットワーク側で具 備する要件等

（3）コグニティブ無線技術を利用した新しい通信システ ムの標準化

これらの標準に関して現在具体的な標準化を行っている団 体として国際電気通信連合 (ITU), 米国電気電子学会 (IEEE) が挙げられる. ITUにおいては主に (1)に関する標 準化を行っている。また, IEEEではIEEE802 及びIEEE 1900 においてコグニティブ無線技術の標準化が行われてい る. IEEE においては (1), (2) 及び (3) の観点から標準化を 行っている。（1）に関してはIEEE1900.1，(2) に関しては IEEE802.21, IEEE1900.2, IEEE1900.3, IEEE1900.4 が相 当する.また，(3)に関してはIEEE 802.22 が相当する．本稿 ではこれらの標準化の概要について述べる.

\section{ITU-R における標準化動向}

ITU-R においては,コグニティブ無線に関して SG（Study Group) 8 配下の WP (Working Party) 8A 内の WG (Working Group）5（New Technology and Services）で 2006 年 3 月会 合より検討が行われている。 この WG5 はソフトウェア無線 
[3]（SDR: Software Defined Radio)，移動通信の IP アプリ ケーション，コグニティブ無線のような新技術やサービスに ついて審議するWGである。各会合のサマリーは以下のよ うになる。

【2006 年 3 月会合】カナダより新規研究課題草案 (Preliminary Draft New Question: PDNQ) としてコグニ ティブ無線が提案される [4].

【2006 年 9 月会合】前回会合で持ち越しされたカナダか らの寄書に基づき, コグニティブ無線に関する新研究課題草 案が審議された。今回会合では，カナダが前回会合の審議を 踏まえた若干の修正を行った寄与文書を提出し, IEEEから は大幅な変更を行った寄与文書が提出され，この二つの文書 をまとめることが，主たる作業となった，日本では総務省が 既に 2005 年 12 月より電波利用料を用いた研究開発（R\&D） として「移動通信システムにおける高度な電波の共同利用に 向けた要素技術の研究開発」を立ち上げ，その中に「コグニ ティブ無線端末機の実現に向けた要素技術の研究開発」 [2], 「コグニティブ無線通信技術の研究開発」［5] という題目でコ グニティブ無線の検討が行われ，また研究成果も出始めてい たため, 新規研究課題草案をたてることに対して特に大きな 問題がないと判断し，この提案に賛同を表明した。そして， 前記総務省電波利用料を利用したコグニティブ無線に関する 研究プロジェクトの成果をベースに寄与文書を提出した。そ してWG5 会合において審議が行われ，コグニティブ無線に 関する新規研究課題が承認され, 出力文書として DNQ の提 案 $(8 \mathrm{~A} / \mathrm{TEMP} / 239)$, WG5 議長報告案 $(8 \mathrm{~A} / \mathrm{TEMP} / 254)$ が 出された。また，同様に引き続き開催された WP8A プレナ リー (Doc.8A/TEMP/239), SG8 会合においても承認され た.

主な研究課題を以下にまとめる [5].

・ITUにおけるコグニティブ無線の定義

・スマート無線, リコンフィグラブル無線等の関連技術 とコグニティブ無線構成要素となり得るその技術検討

・コグニティブ無線に関する主要技術特徴, 要求, 特性 及び利点

・コグニティブ無線の適用アプリケーションと周波数管 理へのインパクト

・運用関連

・移動若しくは他の既存業務（放送，モバイル衛星，固定） と共存可能にする能力

・他のユーザとの共存を保証する周波数共用技術

・ 無線リソースの効率的利用を可能にする方法

【2007 年 6 月会合】前回会合より持ち出しとなった寄与 文書及び今回新たに入力された寄与文書をもとに PDNQに 向けたWorking Documentの編集がなされた.

本標準化は，ITU-RのWG が改組されたため次回からは WP8A ではなくWP5A で議論がされる予定である.

\section{IEEE802 における標準化動向}

\subsection{IEEE802.21}

\section{1 .1 目 的}

IEEE802.21 はコグニティブ無線の標準化とは直接には関 係しない。本 WGの基本的な目的は, IEEE802 で標準化さ れたシステム間若しくは IEEE 802 で標準化されたシステム とセルラ携帯電話システムとの間のハンドオーバの最適化を 行うために必要となるそれぞれのシステム非依存の機構の定 義を行うものである。しかし，システム間のハンドオーバは コグニティブ無線技術において帯域確保のために必要になる 機能の一つであり，また，後述する IEEE1900.4 と非常に考 え方が近いため, 本稿ではその動向について紹介を行う.

\section{1 .2 概 要}

IEEE802.21 の特徵として，図 2 に示すように基本的に 第 2 層と第 3 層との間に Media Independent Handover Function（MIHF）を用意し，情報のやり取りとは別に, IEEE802.11，IEEE802.16 といった各通信システムの 2 層以 下に対しては, Information service, Command service（コ マンドを出す), Event service（link 関連のイベントを受け 付ける）機能を有し，3層以上に対してはInformation service, Command service（コマンドを受ける), Event service（MIH 関連のイベントを出す)機能を有している $[6]$.

4.1 .3 現状

標準化ドラフトドキュメントは 2007 年 12 月現在，バー ジョン 8.0 (以下,バージョンは $\mathrm{v}$ と表記する)に進んでいる. また，WG内の Lettter Ballotも通過し，WG内外を問わず 新たに構成されたSponsor MemberによるInitial Sponsor Ballot も2007年 8〜9月に行われた. Sponsor member は 165 名で 2007 年 9 月 17 日にBallotが終了し, 承認率が $62 \%$ で 650 のコメントが来ており，現状そのコメントを受け たドラフトの修正を行っているところである.

\subsection{IEEE802.22}

\subsection{1 目 的}

IEEE802.22は54 MHzから $862 \mathrm{MHz}$ の米国における $\mathrm{VHF} / \mathrm{UHF}$ 帯におけるテレビ放送と同一周波数帯で，周波 数共用を行いながら point-multipoint (P-MP) の固定通信 を実現するWireless Regional Area Network（WRAN）の Medium Access Control (MAC) layer と Physical (PHY) Layerの標準化を行うWGである。日本でも米国でも同様 であるが，すべての地域ですべてのテレビチャネルが使用さ れているわけではない，場所によっては特定のテレビチャネ ルは使用されていない場合がある（これをWhite space と呼 ぶ)。この White space を一次周波数利用者 (primary user) に干渉を与えない範囲で二次周波数利用者に使用を許可する ことを検討するものである。この場合干渉量が動的に変化す ると対応が困難になるため, システムとしては以下の想定を 置いている. 
ハンドオーバ決定, 伝送, アプリケーション部

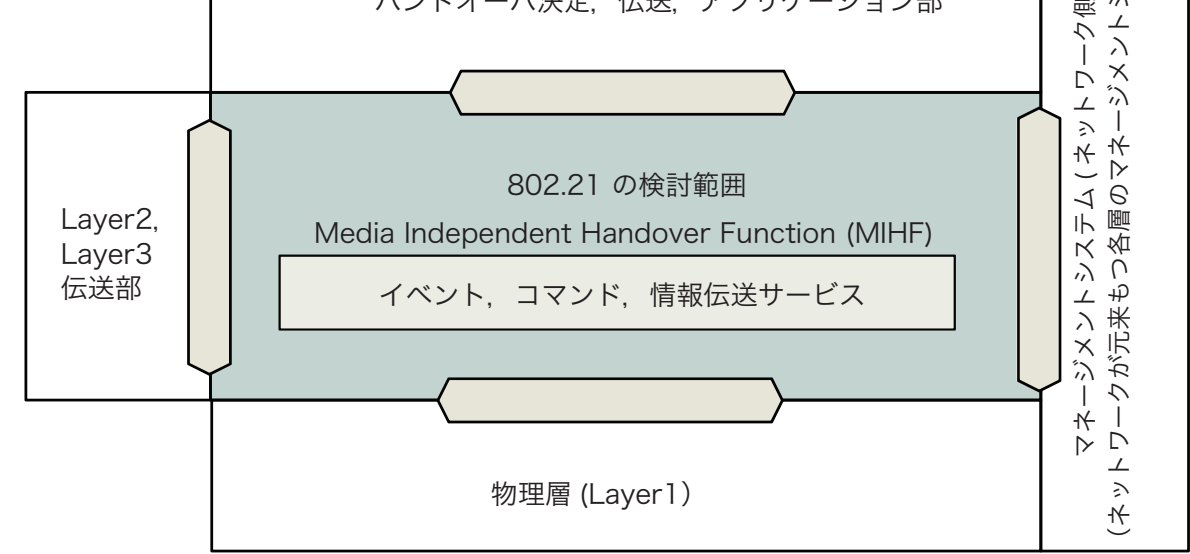

サービスアクセスポイント (SAP)

図 2 IEEE 802.21 のレファレンスモデル（ワーキンググループに提出されている資料をもとに書 かれたイメージ図)

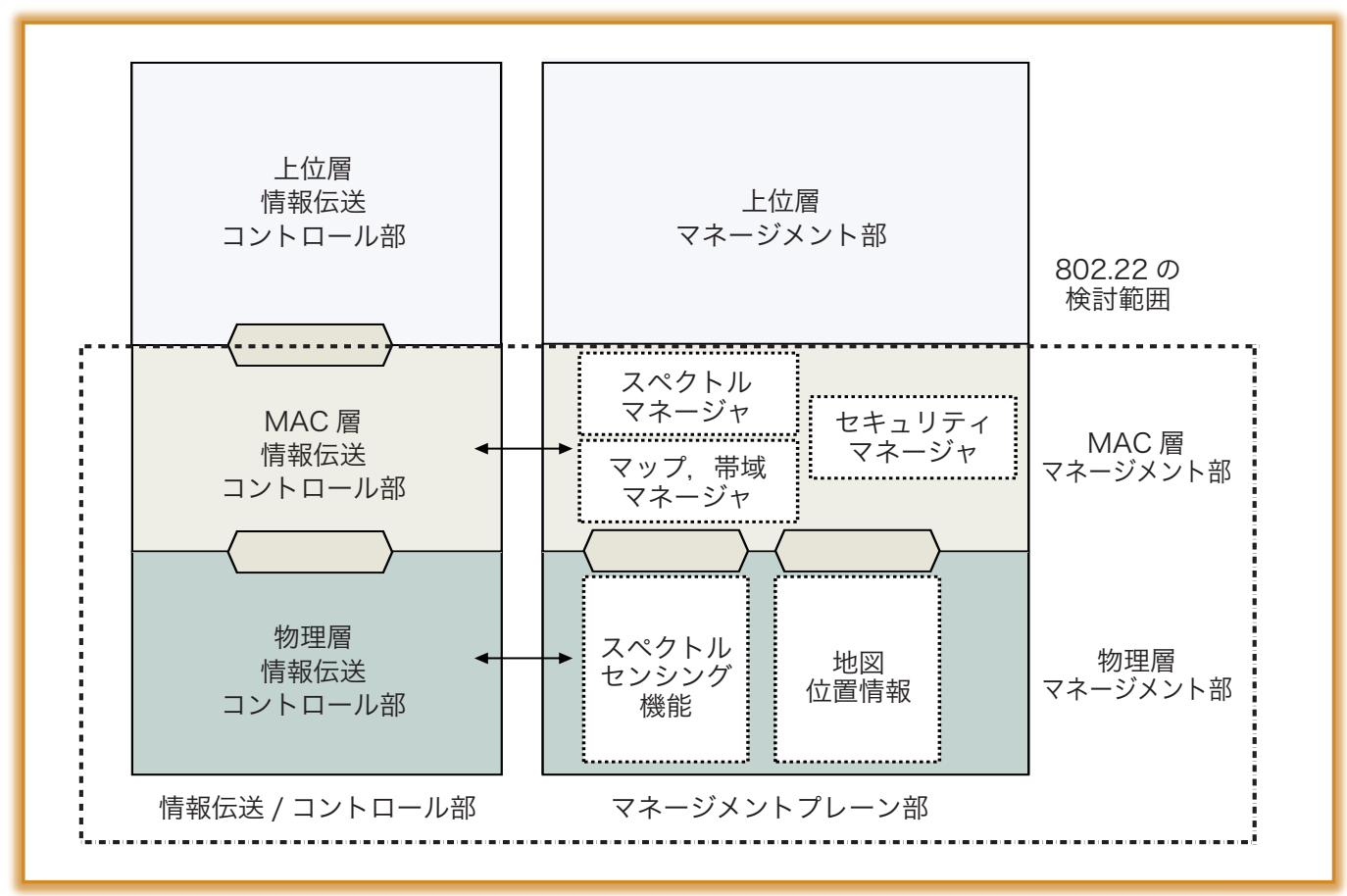

図 3 IEEE802.22 の標準化対象（ワーキンググループに提出されている資料をもとに書かれた イメージ図)

( a ) 固定の P-MP 通信のみを対象

（b）基地局は専門家によって設置

（c） センシングによって更新される最新のデータベース をもつ

（ d ） 基地局アンテナ高は地上から $75 \mathrm{~m}$ 程度の高さに設置

（e）ユーザ側も基地局側と関連づけられ，地上から 10 $\mathrm{m}$ 程度の高さに設置

（f） デバイスが地図位置情報（Geo-location）を利用する
このIEEE802.22 は本稿で紹介する標準化の中で唯一コグ ニティブ無線技術を利用したシステムの標準化を行っている WG である. 具体的には図 3 の点線で示す部分の標準化を行 う [7].

4.2.2 特徵

システムの特徵としては, 通信エリアは半径 $30 \mathrm{~km}$ 程度 の Regional Areaを想定し, 1 チャネル当りの帯域幅はテレ ビの $1 \mathrm{ch}$ 分に相当する $6 \sim 8 \mathrm{MHz}$ ，そして当該周波数帯で 
表 1 IEEE802.22 のシステムパラメータ

\begin{tabular}{|l|l|}
\multicolumn{1}{c|}{ パラメータ } & \multicolumn{1}{c}{ 仕様 } \\
\hline 周波数帯 & $54 \sim 862 \mathrm{MHz}$ \\
\hline 帯域幅 & 6 and/or 7, and $/$ or $8 \mathrm{MHz}$ \\
\hline データレート & $4.84 \sim 24.2 \mathrm{Mbps}$ \\
\hline 周波数利用効率 & $0.81 \sim 4.03 \mathrm{bps/Hz}$ \\
\hline 変調方式 & $\mathrm{QPSK}, 16 \mathrm{AM}, 64 \mathrm{QAM}$ \\
\hline 誤り訂正符号化率 & $1 / 2,2 / 3,3 / 4,5 / 6$ \\
\hline 最大放射電力 & $4 \mathrm{~W}$ \\
\hline 多元接続 & $\mathrm{OFDMA}$ \\
\hline FFT の本数 & 2048 \\
\hline シンボル長に対するガード時間 & $1 / 4,1 / 8,1 / 16,1 / 32$ \\
\hline 複信方式 & 時間分割複信(TDD) \\
\hline
\end{tabular}

利用されているテレビ放送，ワイヤレスマイク等への干渉を 回避しつつ独自の point-multipoint の固定通信を実現するこ とが挙げられる。また，FCC等の報告命令（Report and Order, R\&O)，規制制定告示 (Notice of Proposed Rule Making, NPRM）にも迅速に対応をしている．想定するシス テムパラメー夕を表 1 にまとめる。基本的には通信方式は OFDMA 型の通信システムを想定している。またここシ ステムが保護すべき対象としては, (a) 現行のアナログテレビ 放送 NTSC（2009年 2 月 17 日にディジタル放送に移行予 定 ), (b) ATSC (Advanced Television Systems Committee）のディジタルテレビ放送，（c）ワイヤレスマイク（FCC Part 74 デバイス)である。 そして，この保護する対象との共 存を図るためにコグニティブ無線技術の導入を行㧍うとして いるのが大きな特徴である。この中でも特にワイヤレスマイ クとの共存の方法に関しては, Task Group 1 (IEEE802.22.1) の中で検討が行われている. 具体的な要素技術としては, (1) 免許を有する無線局の保護領域外に IEEE802.22 システムが いるかどうかを判断する Geo-locationの利活用，（2）テレビ チャネルの使用の有無を検出するために一定のしきい值で無 線の電波利用環境を認識するスペクトルセンシング技術の利 活用, (3) 既存局からどのチャネルが利用可能かを示す制御信 号を送信してもらう，制御信号の利活用が挙げられる。この 中でも特に(1)と (2)についてはそれぞれアドホックグループ がWG内で設置され，検討が進められている。（2）に関して は既に目標とされる検出信号電力が (a) NTSCに対しては - $94 \mathrm{dBm}$ (測定帯域幅 $6 \mathrm{MHz}$ ), (b) ATSCに対しては - $116 \mathrm{dBm}$ （測定帯域幅 $6 \mathrm{MHz}$ )，(c) ワイヤレスマイク - $107 \mathrm{dBm}$ （測定帯域幅 $200 \mathrm{kHz}$ ）と大変厳しいセンシング 能力が IEEE802.22 の機器に要求がされており [8], この要 求に今後どのように対応していくのかが問題となる.

4.2 .3 現状

2004 年 9 月に Project Authorization Request (PAR) が承
認され，2005 年 1 月より標準化のための審議が開始された. そして 2005 年 9 月にはシステムの提案募集がされ, 2006 年 3 月にはすべての提案が一本化され標準化ドラフトドキュ メントの作成が開始された。 2007 年 11 月現在，当該標準化 ドラフトドキュメントをWG内の Letter Ballotをかけるべ く審議が進められている。また，IEEE802.22.1に関しても 標準化ドラフトドキュメント v1.0の Letter Ballot ${ }^{\left({ }_{i} 1\right)}$ が行 われたが，目標とする $75 \%$ 以上の承認を得ることができず コメントに基づいた修正を行い v2.0 作成を行い 再 ballotが 行われているところである.

\section{IEEE1900 における標準化動向}

\subsection{IEEE1900 (SCC41)}

IEEE1900 は 2005 年の第 1 四半期に IEEE Communications Society と IEEE Electromagnetic Compatibility (EMC) Societyが共同で設立したStandard Committee で ある。目的は次世代の無線及び Spectrum management を開 発する上で必要となる新しい技術をサポートするための標準 を決めることにある。この IEEE1900のマネージメントの もと，後述する IEEE1900.1, IEEE1900.2, IEEE1900.3 と いったWG及び，後にIEEE1900.3 と統合化される IEEE1900.A，後に IEEE1900.4 となる IEEE1900.B の活動 が行われていた。しかし， 2007 年 3 月 22 日, IEEE Standard Board はこのIEEE1900を Standards Coordinating Committee 41 (SCC41), Dynamic Spectrum Access Networks（DySPAN）という組織に再編することに承認し た。再編後もスポンサーとなるソサイエテイは変わらず，ま た，活動しているWGもそのまま IEEE1900の呼称は引き 続き使用することになっている。基本的にはSCC41は Dynamic Spectrum Access Network の分野の標準化プロ ジェクトを支援し IEEEの標準化間の協調と情報交換を促 進することが目的である. 2007 年 12 月現在, 次節より示す 四つのWG が活動を行っている.SCC41のミーティングは 年に 3 回 (2007 年は 4 月, 7 月, 12 月, 2008 年は 3 月, 7 月, 10 月）行われ，各WGはこの SCC41 ミーティング時以外に も適宜会合がもたれている。ホームページは http://www. scc41.org/である.

\subsection{IEEE1900.1}

\section{2 .1 目 的}

この標準化 WG は Spectrum management, Cognitive radio, Policy Defined Radio, Adaptive Radio, Software defined radio 等の次世代無線通信システムの技術分野の中で かぎになるコンセプト，用語を詳細に定義，説明することに ある。また標準化資料の中ではどのようにこれらのコンセプ トが関連づけられるのかも決めることを目的にしている。こ の標準化のゴールは非常にITU-WP8A と似ており，その一

（注 1）：IEEE 標準化ドキュメントの承認を行う過程の第 1 段階にあた り，各委員会の投票権所有者による投票で $75 \%$ 以上の賛同が得られるこ とが必要. 
部はITU-WP8A においても米国若しくはIEEE の名前で寄 与文書の形で入力されつつある.

5.2 .2 現在までの進ちょく

本標準化 WG の進ちょく状況は以下のようになっている.

- Project Authorization Request(PAR)が承認される (2005 年 3 月 4 日).

- IEEE1900.1の draft がWG 内で承認される（2007 年 7 月 9 日).

・ Revised されたPARの承認が IEEE-SA 内で承認され る.

・ Ballotへの招待がなされ, 83 機関が Ballot チームに入 る(2007 年 7 月〜 8 月).

- Mandatory Editorial Coordination Review が終了する (2007 年 8 月).

- project sponsor Communications Society Boardによる ballot に対する承認がなされる (2007 年 8 月).

・ Initial Ballotが行われる（2007 年 9 月 7 日〜 2007 年 10 月 7 日). 結果は 52 が肯定的な投票, 10 が negative な 投票であり，84\%が承認した。 そして 454 のコメント が提出された。

- Ballotの結果に基づき Ballot Comment Resolution Group（2007 年 10 月 7 日〜現在）が活動中, 2007 年中 にComment resolutionを終了する予定.

\subsection{IEEE1900.2}

\subsection{1 目 的}

本標準化 WG は帯域内及び近接チャネルからの干渉量及 び無線システム間で共存可能性を解析するために推奨される 手法について検討をしている，基本的には対象とする干渉及 び共存方法についてのシナリオを決め, そのシナリオに合わ せ測定結果に基づき干渉を弁別し，その後，モデリング，解 析, テストの結果, 干渉が非常に害を及ぼすものかどうかを 判断するために必要となる方法について明記している.

\subsection{2 現在までの進ちょく}

本標準化 WG の進ちょく状況は以下のようになっている.

- Project Authorization Request(PAR)が承認される (2005 年 2 月).

- Initial Ballot が行われる (2007 年 8 月 3 日締切り)。 112 人のメンバにより評価され，319 のコメントが提出され た. 現在コメントに従い修正が行われているところで ある. 2007 年 10 月現在, 再 ballot の結果 56 のコメン トが残っており，2008 年 1 月に再 ballotが行われた結 果通過した。現在, IEEEの標準化コミティでの最終 承認にかける準備が行われている.

\subsection{IEEE1900.3, IEEE1900.A}

IEEE1900.3 は IEEE1900 発足時にはSoftware defined radioの Software Module の適合性評価のために推奨される 手法について検討がされてきた. しかし, Software Module の評価は作り手によって多くの選択肢があり, 困難を極める が狭い範囲の標準化になることが懸念され, 実際スケジュー
ルどおりに運ばなかったことと, IEEE1900.Aとして, Dynamic Spectrum Access を利用した無線システムに対す る各種規制 (regulatory) への適合性の評価方法に関しての標 準化を検討していたこともあり，この二つの WGを統合化 させ新しくIEEE1900.3 として標準化検討 WG を発足させ ることになった。 現在, 新しい, Project Authorization Request（PAR）が準備され, IEEEの Standards Association/Standards Board (SASB), IEEE-SASB New Standards Committee (NESCOM), IEEE EMC Society Standards Committee (SDCOM) での承認待ちの状態である. この 新しいIEEE1900.3の Scope は Dynamic Spectrum Access を行うことができる無線システムの各種規制への適 合性及びその利害関係者（stakeholder）による評価のために 使われるテスト及び解析手法について決定を行うものであ る.この Dynamic Spectrum Access を行うことができる無 線システムとは例えば, DARPA XG, IEEE802.22, TV White spece を用いた通信システムが挙げられる. 現在の活 動は，この Dynamic Spectrum Access を行うことができる 無線システムに関する利害関係者との情報交換及びテストフ レームワークの構築の検討が行われている.

\subsection{IEEE1900.4 \\ 5.5 .1 目 的}

本標準化WGの目的は, 複数の RAT (Radio Access Technology, 無線アクセス技術) が存在する環境において無 線システム全体の収容能力とサービス品質を向上させるため に必要となるシステムアーキテクチャ, ネットワーク側, 端 末側で具備する機能の定義, requirementをまとめることに ある。ここでRAT とは, 例えば, 第 3 世代移動通信システ ムや無線 LAN, WiMAXのような, 無線アクセス技術のこ とである。この無線資源利用の最適化を実現するために, IEEE1900.4 では, ネットワーク再構成マネージャ（Network Reconfiguration Manager, NRM), 端末再構成マネージャ (Terminal Reconfiguration Manager, TRM)，そして，それ らの間で通信される情報を定義する。そして，異種無線アク セスネットワークに抢いて, ネットワークと端末に意思決定 の機能を分散させ，周波数の利用制御を含む無線資源利用の 最適化を支援する $[10]$. 図 4 に，想定するネットワークのイ メージを示す [5]。ここでは, 単一の無線アクセス技術から 構成される基地局やネットワークを含むネットワーク構成要 素全体をまとめて, Radio Access Network（RAN）と定義 している.また，複数の RAN から構成されているシステム 運用の単位を Composite Wireless Network（CWN）と定義 する，CWNを運用するオペレー夕は，単一の場合もあれば 複数の場合も考えられる. 端末は, 複数のアクセス技術をサ ポートしているだけでなく，それらを同時に使用することも 想定する. IEEE1900.4では,物理的な無線リンクの上にマッ ピングされる論理的なチャネルを定義しており，これを Radio Enabler（RE）と呼んでいる. REは，デー夕通信と 同一の RAN（in-band）を使用することもあれば，専用の 


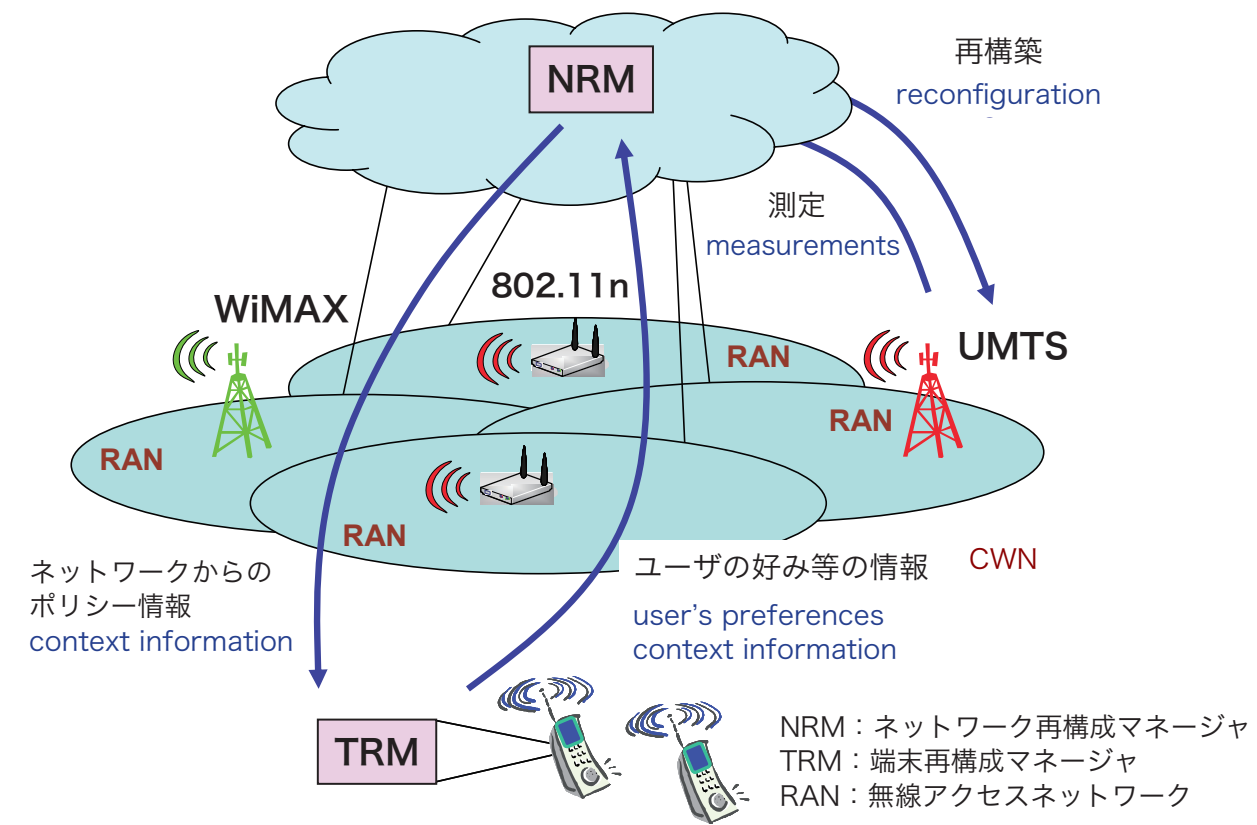

図 4 IEEE1900.4 で想定するネットワークのイメージ[10]

RAN（out-of-band）を使用することもある。また，単一の RAN にマッピングする場合もあるし，複数の場合も考えら れる。

\section{5 .2 現在までの進ちょく}

IEEE1900.4 は 2006 年 12 月にPARが承認され，第 1 回 目の会合が 2007 年 2 月に行われた。以来 2007 年の 12 月の 時点で, 6 回の会合が開催されている $(2007$ 年 2 月, 3 月, 6 月, 7 月，10月，12月). また本標準化の投票権は個人ベースで はなく所属する機関ごとに投票権がある。2007 年 12 月の時 点で 21 機関が投票権をもつ. 会合は基本的には標準化ドラ フトドキュメントの章構成に基づき入力文書を募集し，入力 文書に基づいた審議の結果，各ドキユメントの作成を行い承 認をとるという流れになる。現在，2007 年 12 月会合の時点 で標準化ドラフトドキュメント v1.2の作成が終了した。

\section{5 .3 特徵}

IEEE1900.4の特徵としては，対象とする利用事例（Use Case)を三つに限定し標準化を行っているところである.

まずは図 5 に示す Dynamic Spectrum Assignmentであ る。これは Regulatorまたは Network Management Authority（これらを合わせて，Network Management Entity と呼 ぶ）が決定する制限規則に従い，CWN 内の RAN に対して, 一定の地域や時間に運用される周波数帯域を動的に割り当て る処理及び機構のことをいう. 同図では二つの周波数帯域 Band \#1 と Band \#2 が，異なるRATに対して割り当てら れていると仮定しており，動的にその利用できる带域幅が変 化するものである。この利用事例を適用する例としては，第 3 世代携帯電話に使われていた周波数帯域をその使用率に合
わせてダイナミックにWiMAX 用に再割当する場合等が考 えられる。

次は図 6 に示す Dynamic Spectrum Access（DS-Access） である。これは, 異なる無線アクセスネットワークと端末が, 全部あるいは部分的に重複する周波数帯域を複数の RATに おいて動的に使用する場合に必要となる処理及び機構のこと をいう。この際，制限規則に従い，相互干渉が許容されるレ ベルに収まるように制御される。また，ネットワークと端末 間の調整は，必要になる場合もあれば，ならない場合もある。 この利用事例を適用する例として，使用されていないテレビ 周波数帯域にIEEE 802.22 のようなアンライセンスの二次 利用者がアクセスする場合が考えられる。

最後は図 7 に示す Distributed Radio Resource Usage Optimization である。これは，ネットワークと端末が協調す ることにより，無線資源の最適な利用を分散的に行うことを 可能にする処理及び機構のことをいう。この利用事例を適用 する例として, (1) 通信に使用している IEEE 802.11g のアク セスポイントにおいて接続数が増加してパケットロスが増加 したので他のアクセスポイントに接続する，(2) アプリケー ションの実行に必要な帯域が得られないので複数の無線リン クを同時に確立して帯域を統合する場合，等が考えられる。

また，IEEE1900.4で検討をしているシステムアーキテク チャ（System Architecture）を図 8 にそれぞれ示す。ネット ワーク側には，NRM， RRC， RMC，NMA という四つのエン ティティ（entity）で定義をしている. Network Reconfiguration Manager (NRM) は, 周波数利用の最適化をネットワー クと端末に分散させるために, CWN と端末を管理するエン 


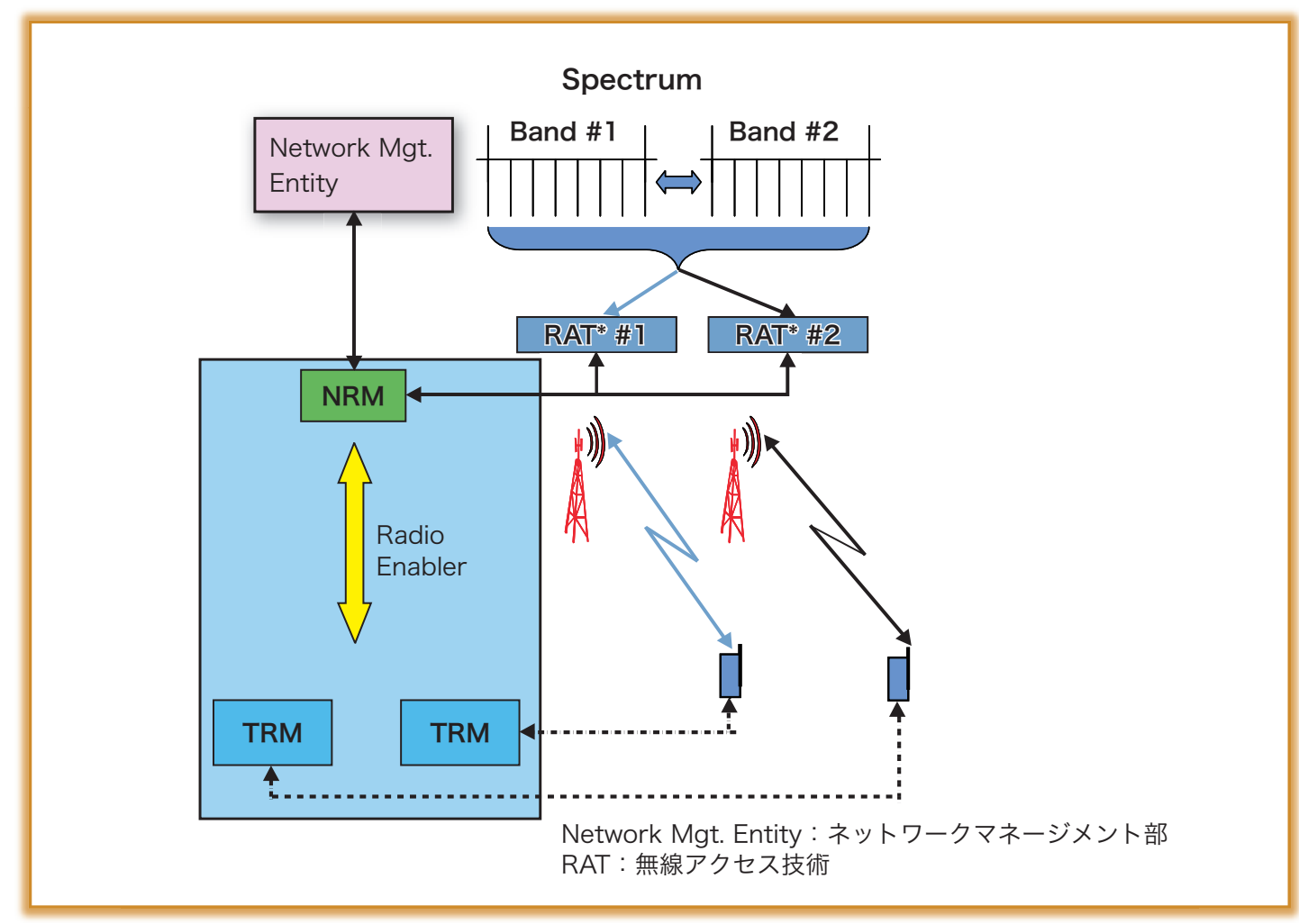

図 5 IEEE1900.4 で検討される利用事例 1 (Dynamic Spectrum Assignment) [10]

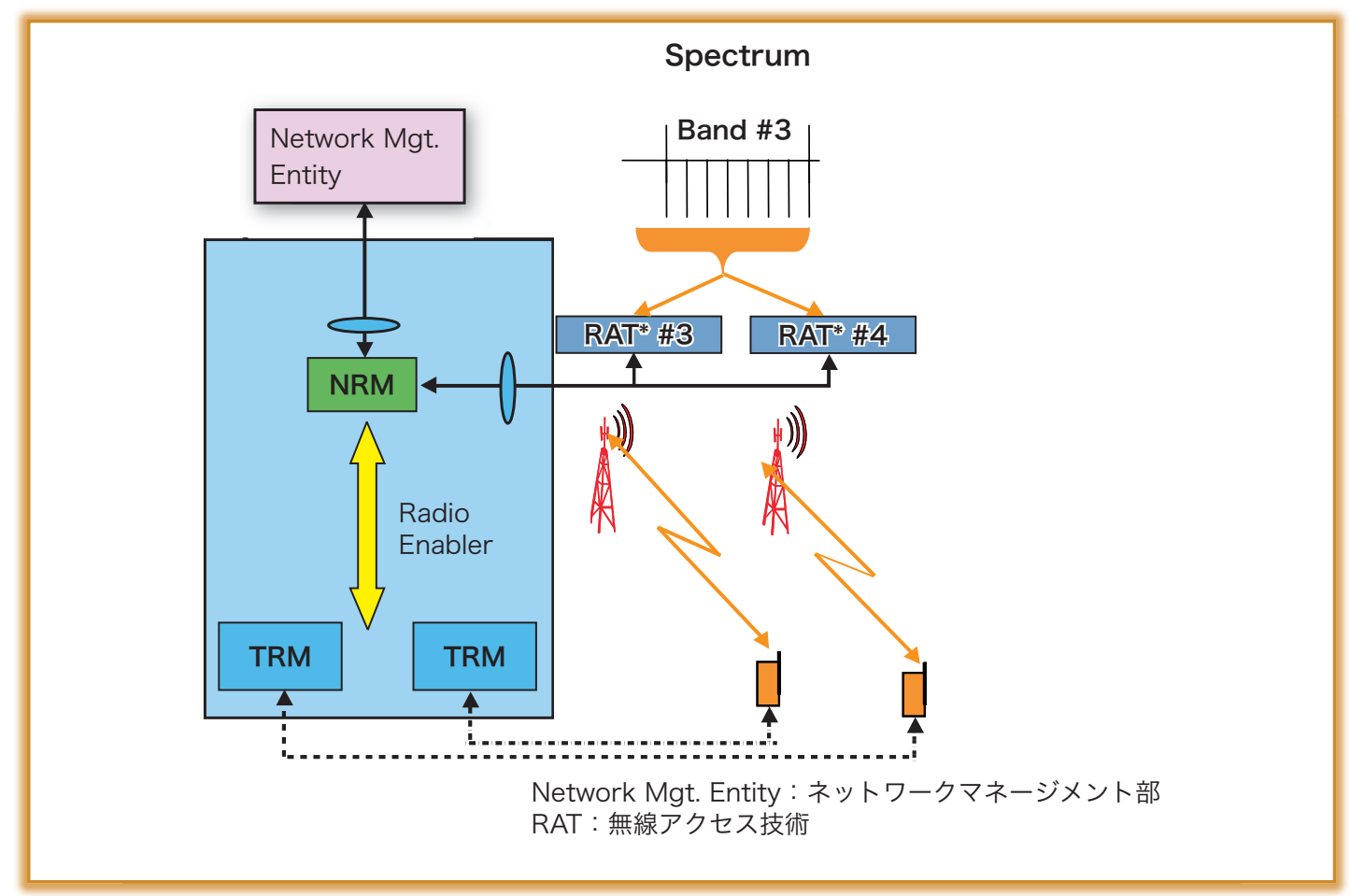

図 6 IEEE1900.4で検討される利用事例 2 (Dynamic Spectrum Access（DS-Access））[10］

ティティである. RAN Reconfiguration Controller(RRC)は, NRM によるRAN の再構成を可能にするエンティティであ る. Radio Measurement Collector (RMC) は，RANに関す る測定結果を NRMに提供するエンティティである. Network Management Authority（NMA）とは，周波数の利
用に関してNRM に指示を行う権限をもったエンティティで ある。

一方，端末側には，TRM，TRC，TMCという三つの エンティティで定義をしている. Terminal Reconfiguration Manager（TRM）は，NRMによって定義された枠組みの中 


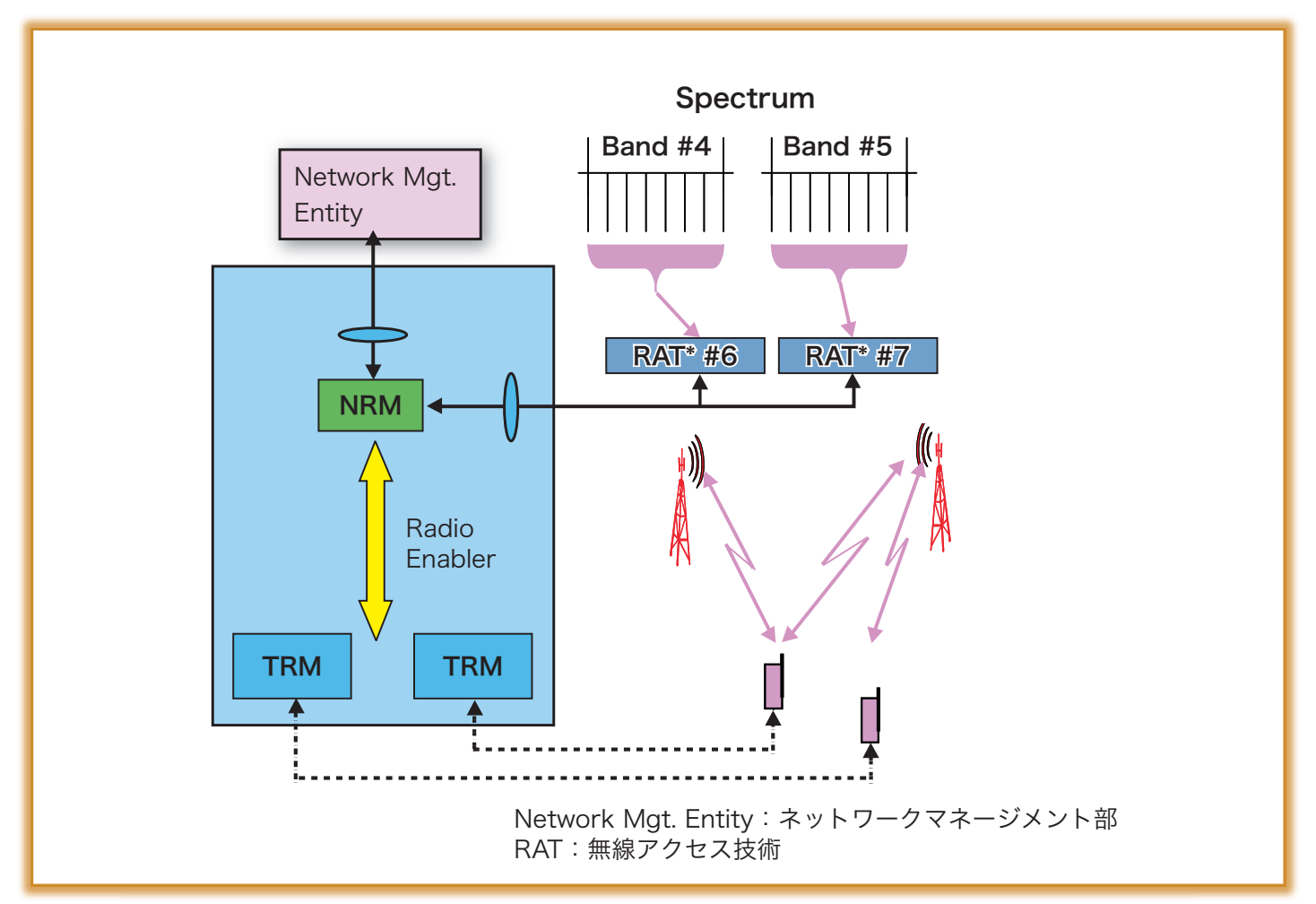

図 7 IEEE1900.4 で検討される利用事例 3(Distributed Radio Resource Usage Optimization) [10]

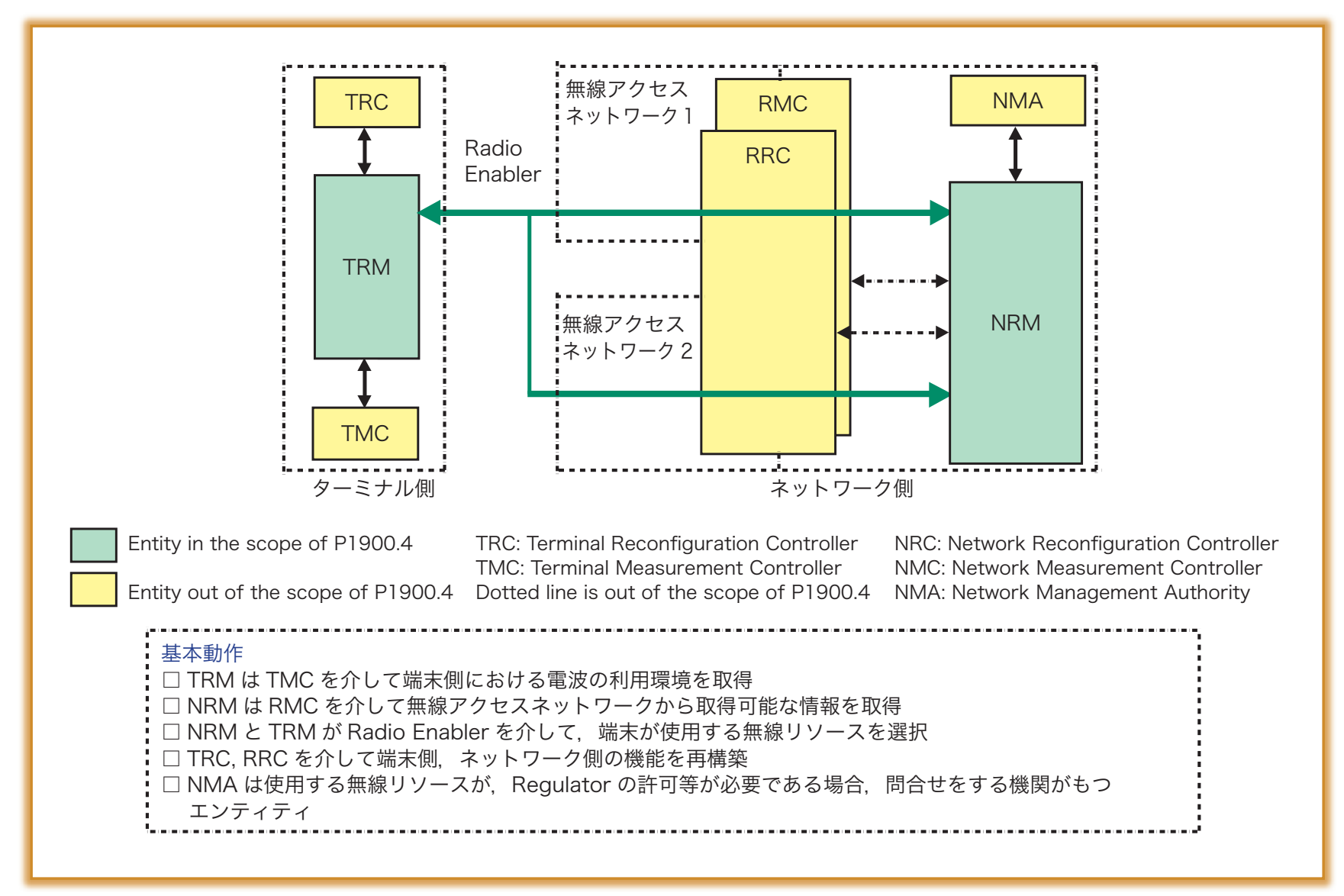

図 8 IEEE1900.4で検討されるシステムアーキテクチャ [10］ 
で，ユーザプリファレンスと利用可能なコンテクスト情報と の整合性をとりながら，周波数利用の最適化をネットワーク と端末に分散させるために端末を制御するエンティティであ る. Terminal Reconfiguration Controller (TRC) は, TRM による端末の再構成を実行するエンティティである. Terminal Measurement Collector (TMC) は, 端末で取得可 能な電波の利用状況を取得し, その測定結果をTRMに提供 するエンティティである，今後は，NRM と TRM の内部の 機能ブロック並びに NRM と TRM との間でやり取りされる Information model 及びやり取りを行うための手順（procedure）に関してのガイドラインがまとめられ，標準化ドラフ トドキュメントがまとめられた後, Sponsor Ballotが行われ る予定である. また現在, この NRM と TRM との具体的な 通信方式，プロトコル等を定義するための標準化プロジェク 卜（番号が付くとするとIEEE1900.4a か若しくは IEEE1900. 4.1) も提案されつつあり, このIEEE1900.4のド キュメントをもとにシステムの標準化等も行われる可能性も 検討されている. また, 最後に図 9 にIEEE1900.4の参照モ デルを示す. 図 2 と図 9 を比較すると IEEE 802.21 は基本的 には第 3 層より下の層でシステムの切換のための情報収集, イベントの作成, コマンドの生成を行うのに対し, IEEE1900.4では 3 層より下の層には TMC/RMC 若しくは

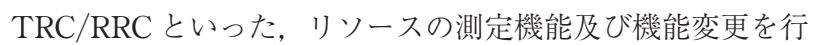
う機能のみをもたせ, NRM/TRM といった機構は 3 層以上 にもたせるところが特徵である。

\section{6. 日本の動向と今後の展開}

以上，コグニティブ無線技術を用いた標準化動向をまとめ てきたが, 日本に抢いては現状, 同一周波数帯で複数の事業 者に免許を与えたり $(2.4 \mathrm{GHz}$ 帯 ISM バンドは除く), 現状 のサービスを行っている周波数帯に重畳して新しい通信シス テムの使用を許可するといった政策はまだ行われていない (UWB システムは除く). 現在は研究開発のフェーズという 位置付けでこのコグニティブ無線を取り扱っているところで ある．具体的には前述したように総務省に抒いては電波利用 料を用いた研究開発 $(R \& D)$ として「移動通信システムにおけ る高度な電波の共同利用に向けた要素技術の研究開発」を立 ち上げその中で「コグニティブ無線端末機の実現に向けた要 素技術の研究開発」[2],「コグニティブ無線通信技術の研究開 発」[5]という題目で 2005 年 12 月より 2008 年 3 月まで検討 が行われている $[11]$. また，2008 年度に向けた「ICT 国際競 争力強化重点技術戦略」18 テーマの一つに挙げられ, 国とし ての研究開発を支える土台は確実に築かれている。 また，上 記のITU 等に対しても積極的に寄与を行うように呼びかけ は行っている. しかし, 研究開発を行う側はコグニティブ無 線技術の研究開発の土台にこたえるだけの十分な準備はでき ているかどうか筆者は非常に疑問をもっている，そしてこの コグニティブ無線に関しては筆者にはどうも行政側の方がコ グニティブ無線技術に関しては研究者側を先んじて進んでい るような気がする. 理由は, 上記標準化に参加をし, 寄与文 書による貢献並びに動向調査を行っている人数の少なさであ る．例えば現状の IEEE802.21の標準化ドラフトドキュメン

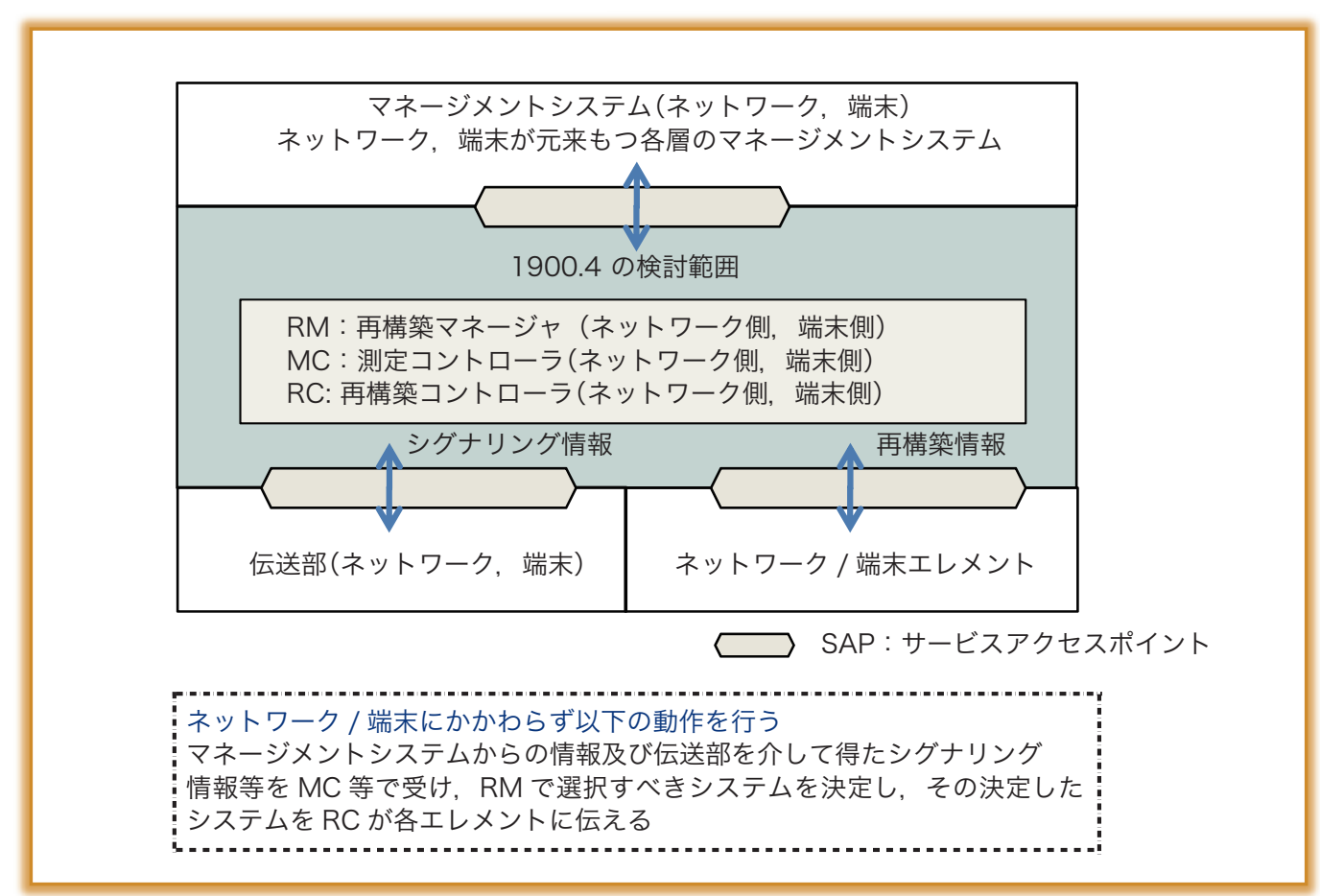

図 9 IEEE1900.4 のレファレンスモデルの例（ワーキンググループに提出されている資料をもと に書かれたイメージ図) 
トに打いて見ることのできる日本人名は 4 人ほどしか見あた らない（現実的には 1 名のみが現在も貢献していると推察さ れる)。また, IEEE 802.22 も早期から現在まで会合に参加 し，投票権を有している方は日本からは1名しかいない。ま た，IEEE1900.4 等においても第 1 回会合から標準化ドラフ トドキュメントの半分が決定した 4 回会合までに参加してい る機関は 1 機関 (筆者が所属する NICT) のみである（現状は 11 機関まで増えた)。こんなに少ない投票権をもった参加機 関数では，会議のコントロールは事実上無理であり，思った 仕様を標準に入れることはできない。ではコグニティブ技術 は今後使用されないのか?

現在，移動通信に適した $\mathrm{VHF} / \mathrm{UHF}$ 帯から $6 \mathrm{GHz}$ 以下の 周波数带は 2007 年 12 月時点においても既に逼迫しており, 今後 $2010 ２ 015$ 年までに出てくる新しいシステムは，確実 に現在のシステムよりもブロードバンド化が求められてく る。ただし，ブロードバンド化はイコール通信エリアの縮小 にもつながるので，ブロードバンド化はより複数の通信シス テムを同一周波数带でマネージメントすることに適している ものである.すなわち何らかの形で我々はこのコグニティブ 無線技術と対峙せざるを得ないときがくる.

また,「本当にすべての人が利用しようとしている電波の利 用状況をすべて管理できるのか」という疑問もあるかもしれ ないがこれもナンセンスである。現状の Google 社が運営す る Gmail で一人当りに無料で割り振られている GByteオー ダの記憶容量を考えると, だれも今から 10 年後の一人当り が無料で使用できる記憶容量は予測はできないのである。す なわち, “そもそもコグニティブ無線通信技術など実現できる のだろうか”という非常に Low level な, “立ち止まった”議論 はやめ，積極的にこの思想を取り込み，この「コグニティブ 無線通信技術」の視点から現在の研究開発活動を今一度見直 す必要性がある。理由は世界中が「コグニティブ無線通信技 術」の実用化に向けて何らかの形で動き出しているからであ る. 日本のこのような一時の“立ち止まり”が多くの標準化へ の貢献を阻害してきた。標準化活動とは自分の研究開発成果 ( = 知的所有権)を入れ込久日本加ら日本外への不毛な打金の 流出を防ぐことであると筆者は考える，そのためには標準化 活動に最初から参加し，会合の流れを作り，自分たちの知的 所有権をできるだけ多く入れることである。これがひいては 日本の国際競争力アップにつながることになる。もちろん標 準化されたからといって必ずしも使われるとは限らない，し かし, 使われる標準化だけ参加するというのは非常に難しい. それはあまりにも虫がいい話である。地道な努力が標準化策 定につながることになる，本稿が少しでも標準化に興味を もって頂ける糸口になれば幸いである.

\section{文献}

１1］原田博司, “コグニティブ無線端末機の実現に向けた要 素技術の研究開発,”信学技報, SR2005-18, May 2005.

［2］原田博司, “コグニティブ無線通信〜 NiCT に扮ける研 究開発の成果より,”ITU ジャーナル，2007 年 2 月.

［3］鈴木康夫，荒木純道，“ソフトウェア無線機とその国内 における開発の現状, ”信学論 (B), vol. J84-B, no. 7, pp. 1120-1131, July 2001

４4］吉野 仁，“ITU-Rにおけるコグニティブ無線の標準 化活動の状況, ”信学技報, SR2006-58, Nov. 2006.

［5］野原光夫, “コグニティブ無線通信の研究開発動向〜ネ ットワーク適用の観点から,” ITU ジャーナル，Feb. 2007.

[6] IEEE802.21/D7.1, "Draft standard for local and metropolitan area networks: Media independent handover services," Aug. 2007.

[7] IEEE802.22-07/0461r0

［8］佐々木重信, “IEEE802.22 における標準化動向,”信学 技報，SR2006-59, Nov. 2006 .

[9] IEEEP1900.2/D4.00, "Draft recommended practice for the analysis of in-band and adjacent band interference and coexistence between radio systems," Oct. 2007.

[10］石津健太郎，村上 誉，フィリン スタニスラブ，原 田博司, 宮本 剛, チャン ハグエン, 加藤修三, “IEEE P1900.4 の動向と NICT の取り組み, ”信学技報, SR2007-58, Nov. 2007.

[11］小泉純子, “総務省の電波政策と最近の動向,”信学技 報，SR2007-60, Nov. 2006 .

(平成 19 年 12 月 25 日受付)

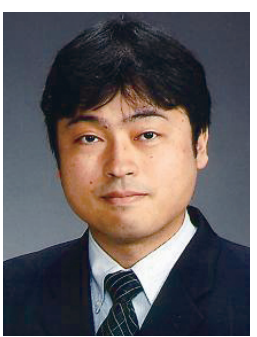

原田＼cjkstart博司 (正員)

平 7 阪大 $\cdot$ 工・通信博士後期課程了. 同 年郵政省通信総合研究所（現 独立行政法 人 情報通信研究機構 (NICT)) 入所. 以来 ディジタル信号処理を用いた移動通信技 術, ソフトウェア無線技術，コグニティブ 無線技術，ミリ波WPAN システム（IEEE 802.15.3c)）の研究開発・標準化に従事. 平 8 〜 オランダ・デルフト工大, ポスト ドクトラルフェロー. 現在, NICT, 新世代ワイヤレス研究センター, ユビキタスモバイルグループ, グループリーダ. 本会ソフトウェ ア無線研究専門委員会専門委員長 (平 17 年 5 月 19 年 5 月), 電 気通信大学客員教授 (平 18 ～現在), 米国ソフトウェア無線 (SDR) フォーラム, Board of Directors (平 19 〜 現在), IEEE SCC41 (1900) Vice Chair (平 20 〜現在)等を歴任. 